\title{
RESTRUKTURYZACJA
}

\section{CYFROWYCH MODELI BIZNESU - PRÓBA KONCEPTUALIZACJI}

DOI: $10.33141 /$ po.2019.12.02

\section{Marek Jabłoński}

\section{Wprowadzenie}

S ystemy produktowo-usługowe (ang. Product-Servi$\checkmark$ ce System - PSS) stanowią obecnie kluczowy trend w zakresie projektowania modeli biznesu. W kontekście cyfryzacji mają one jeszcze większe znaczenie, gdyż to na ich założeniach powstały takie koncepcje, jak: ekonomia współdzielenia (Sharing Economy), duże zbiory danych (Big Data) i gospodarka okrężna (Circular Economy). Transformacja orientacji produktowej na hybrydową - produktowo-usługową wynika w dużym stopniu ze zmian $\mathrm{w}$ otoczeniu makroekonomicznym, gdzie rola usług w gospodarce światowej rośnie. Wynika to z założeń gospodarki sieciowej, gdzie partnerstwo pomiędzy przedsiębiorstwami odgrywa kluczowe znaczenie, co determinuje potrzeby dostrajania do tego celu modeli biznesu. Kombinacja świadczonych usług poprzez dedykowane celowe modele biznesu wypełnia przestrzeń współpracy między partnerami na rzecz zorientowanych na usługi odbiorców. Rozwój usługowego charakteru świadczonego biznesu wspierany jest przez orientację na usługi konsumentów. Gospodarka światowa przekształca się z orientacji produktowej na usługową (Reim i in., 2019; Hakanen i in., 2017, s. 167-178; Kohtamäki i in., 2019, s. 1-13), co generuje powstawanie innowacyjnych modeli biznesu. Cyfrowe modele biznesu skupiają swoją 
uwage na dodawaniu dodatkowych propozycji wartości względem tradycyjnych modeli biznesu. Operacjonalizują $\mathrm{w}$ ten sposób przedmiotowe systemy produktowo-usługowe. Poszerzając łańcuch wartości dodanej o nowe, dodatkowe propozycje wartości, zwiększają zasięg swojego działania, jak również wpisują się w nurt zrównoważonego rozwoju w tym sensie, że zwiększają efektywność biznesu przy ograniczaniu zaangażowanych zasobów. Modele biznesu poprzez skupienie na usłudze maksymalizują swoją funkcjonalność, przez co podważają tradycyjne formuły dostaw produktów, wypierając je poprzez swój systemowy charakter. W kontekście uwarunkowań koncepcji systemów produktowo-usługowych następuje przejście od systemów zorientowanych produktowo (product-oriented services) poprzez systemy zorientowane użytkowo (use-oriented services) do systemów zorientowanych wynikowo (result-oriented services) (Tukker, 2004, s. 248-249). Nie wszystkie cyfrowe modele biznesu w pełni wykorzystują te teoretyczne założenia. Niektóre z nich charakteryzują się labilnością (Jabłoński, 2019), która sprawia, że tracą one swoją atrakcyjność inwestycyjną (Jabłoński, 2015), a wartość, która powinna do nich płynąć, migruje do atrakcyjniejszych modeli biznesu. W tym aspekcie wymagają one restrukturyzacji dla osiągnięcia zdolności modelu biznesu do przechwytywania wartości z rynku oraz zatrzymania wartości w formie zysków, lojalnych klientów i zdolności do utrzymania $\mathrm{w}$ dyspozycyjności wykorzystywanych zasobów. Serwicyzacja to zjawisko, w ramach którego firmy pracujące dotychczas w klasycznym modelu „wyprodukuj i sprzedaj" (make \& sell) (np. firmy produkcyjne) zmieniają swój model biznesu i zaczynają dodawać do swojej oferty usługi lub wręcz całkowicie przechodzą na model usługowy, czyli „wyprodukuj i utrzymaj” (make \& maintain) (Blog FUZERS, 2018). Serwicyzacja jako koncepcja może służyć poprzez swoje ideowe założenie do rewolucyjnych i ewolucyjnych zmian w konfiguracjach modeli biznesu, które mogą wpisywać się $\mathrm{w}$ pojęcie restrukturyzacji. Taka formuła restrukturyzacji opiera się na nowoczesnym podejściu do zarządzania zmianą, a model biznesu i jego atrybuty użyteczności decydują o skuteczności owej restrukturyzacji. Stąd też założenia restrukturyzacji modelu biznesu, procesów, struktur organizacyjnych nie powinny ograniczać się tylko do zmian o charakterze optymalizacyjnym, ale niektóre z obszarów mogą nawet być maksymalizowane dla zapewnienia oczekiwanego efektu poprzez budowę systemowego rozwiązania produktowo-usługowego. Poszerzanie działalności o dodatkowe usługi i stosowanie do ich realizacji nowoczesnych technologii wpływa na zwiększanie przychodów w oparciu o rekonfigurację modeli biznesu. W gospodarce funkcjonalnej konsument nie kupuje samochodu, ale wybiera możliwość odbycia podróży; nie nabywa pralki ani detergentów, lecz opcję prania; nie zaopatruje się w płyty DVD, tylko ogląda film na Netflixie (Blog thinkle, 2019). Restrukturyzacja $\mathrm{w}$ takim ujęciu powinna być realizowana współbieżnie $\mathrm{z}$ rekonfiguracją modeli biznesu dla wytworzenia dodatkowej wartości dodanej.
Celem artykułu jest opracowanie założeń dla modelu restrukturyzacji cyfrowych modeli biznesu. Zakres artykułu obejmuje przegląd literatury przedmiotu w zakresie problematyki restrukturyzacji, serwicyzacji, systemów produktowo-usługowych oraz cyfrowych modeli biznesu. Wyniki badań bibliograficznych, dyskusja w środowisku naukowym oraz doświadczenia autora w kontekście wskazanych przesłanek zmian $\mathrm{w}$ procesie implementacji do gospodarki światowej formuł biznesowych opartych na założeniach gospodarki cyfrowej posłużyły do zdefiniowania luki badawczej. Przedmiotowa luka badawcza opiera się na założeniu, że dotychczasowe doświadczenia opisane w zakresie teorii i praktyki zarządzania nie wskazują rozwiązań w sferze konceptualizacji i operacjonalizacji procesu restrukturyzacji cyfrowych modeli biznesu. Dotychczasowe rozwiązania w zakresie restrukturyzacji przedsiębiorstw działających w biznesie niecyfrowym nie są adekwatne do specyfiki gospodarki cyfrowej. Dlatego też autor niniejszego artykułu podjął się opracowania innowacyjnego, autorskiego modelu restrukturyzacji cyfrowych modeli biznesu opartego na triadzie trzech kluczowych elementów, a mianowicie: serwicyzacja, socjalizacja oraz kreowanie wartości strategicznej. Zaproponowane rozwiązanie w treści artykułu może być użyteczne zarówno w kontekście teoriopoznawczym, jak i dla celów aplikacyjnych. Wyniki badań powinny przyczynić się do lepszego rozpoznania luki poznawczej w tym zakresie. Dyskusja oraz konkluzje powinny zapewnić polemikę w kontekście zaprezentowanych treści. Problemy nierozwiązane ujęto w części artykułu poświęconej wskazaniu przyszłych obszarów penetracji naukowej tego zagadnienia. Kluczowe pytania badawcze, jakie postawiono w przedmiotowym artykule, są następujące:

1. Jak definiować proces restrukturyzacji cyfrowych modeli biznesu?

2. Jakie czynniki determinują potrzeby realizacji procesu restrukturyzacji cyfrowych modeli biznesu?

3. Jaka jest rola serwicyzacji, socjalizacji i wartości strategicznej w procesie restrukturyzacji cyfrowych modeli biznesu?

4. Z jakich komponentów powinien zostać zbudowany model restrukturyzacji cyfrowych modeli biznesu.

Tak postawione pytania badawcze kształtują identyfikację zdefiniowanego problemu naukowego i definiują lukę poznawczą?

\section{Badania bibliograficzne w zakresie pojęć serwicyzacja, socjalizacja oraz modele biznesu}

W celu przeprowadzenia badań bibliograficznych pojęć serwicyzacja, socjalizacja oraz modele biznesu (model biznesu służy kreowaniu wartości) w periodykach naukowych wykorzystano bazy naukowe Scopus oraz ProQuest. Scopus to naukowa baza danych, zawierająca informacje o opublikowanych pracach naukowych, takich jak artykuły w czasopismach naukowych, książki, materiały konferencyjne oraz patenty. Analiza danych umieszczonych przez portal umożliwia wszechstronny przegląd światowych wyników badań naukowych. ProQuest to 
również internetowa baza publikacji elektronicznych. Dzięki rozbudowanej wyszukiwarce stanowi wsparcie dla pracowników naukowych. Ogromne zasoby i narzędzia ProQuest wspierają badania i uczenie się, publikowanie i rozpowszechnianie oraz nabywanie, zarządzanie i odkrywanie zbiorów bibliotecznych. Analizując występowanie terminu „servitization” w powyższych bazach internetowych, wzięto pod uwagę liczbę publikacji zawierających dane słowo w każdym roku, zaczynając od 2010. Uwzględniono wszystkie dostępne typy źródeł: czasopisma naukowe, branżowe, depesze, artykuły i materiały konferencyjne, prace naukowe i raporty, dysertacje i prace dyplomowe, materiały internetowe, czasopisma i inne. $\mathrm{Z}$ powyższej analizy jasno wynika, że w obu bazach danych dostrzega się wzrost występowania terminu „servitization”. Odnotowano również nieznaczną przewagę występowania tego pojęcia w publikacjach zawartych na portalu ProQuest. W bazie internetowej Scopus jedynie w 2015 roku występuje spadek występowalności terminu. Na rysunku 1 wskazano liczbę wystąpień terminu „servitization" w bazach danych ProQuest i Scopus.

Podobną analizę przeprowadzono w stosunku do występowania pojęcia „socialization”. Tutaj również zauważono wzrost liczby publikacji zawierających powyższy termin. W bazie internetowej Scopus znajduje się o wiele mniej publikacji z tym słowem. Na rysunku 2 wskazano liczbę wystąpień pojęcia „socialization” w bazach danych ProQuest i Scopus.

Sytuacja wygląda bardzo podobnie w odniesieniu do pojęcia „business model”. Zaskakujący może być za to fakt, że w 2018 roku odnotowano spadek występowalności pojęcia w bazie danych ProQuest. Na rysunku 3 wskazano liczbę wystąpień pojęcia „business model” w bazach danych ProQuest i Scopus.

Wyniki przeprowadzonych badań wskazują na rosnące zainteresowanie przedmiotowymi pojęciami. Dlatego też dokonując przeglądu literatury przedmiotu w tym zakresie, podjęto się próby przeprowadzenia konceptualizacji tych pojęć w kontekście zagadnienia restrukturyzacji cyfrowych modeli biznesu.

\section{Założenia restrukturyzacji przedsiębiorstw w kontekście cyfrowych modeli biznesu}

$\mathbf{N}$ ajwiększym sukcesem restrukturyzacji nie jest tylko przeprowadzenie procesu naprawy organizacji, lecz przełożenie tego procesu na dynamiczny wzrost. Dla takich założeń nie można zastosować prostych rozwiązań restrukturyzacyjnych. Należy równolegle opracowywać co najmniej dwa alternatywne scenariusze. Jeden minimalistyczny polegający na odnowieniu modelu biznesu w celu zapewnienia przetrwania przedsiębiorstwa, drugi o charakterze wdrożenia radykalnych zmian oparty na rekonfiguracji modelu biznesu w taki sposób, aby wszystkie symptomy kryzysu zamienić na strumień przychodów pochodzących z nowych rynków. W opinii autora taka restrukturyzacja powinna bazować na założeniach systemu produktowo-usługowego, który należy osadzić w rekonfigurowanym

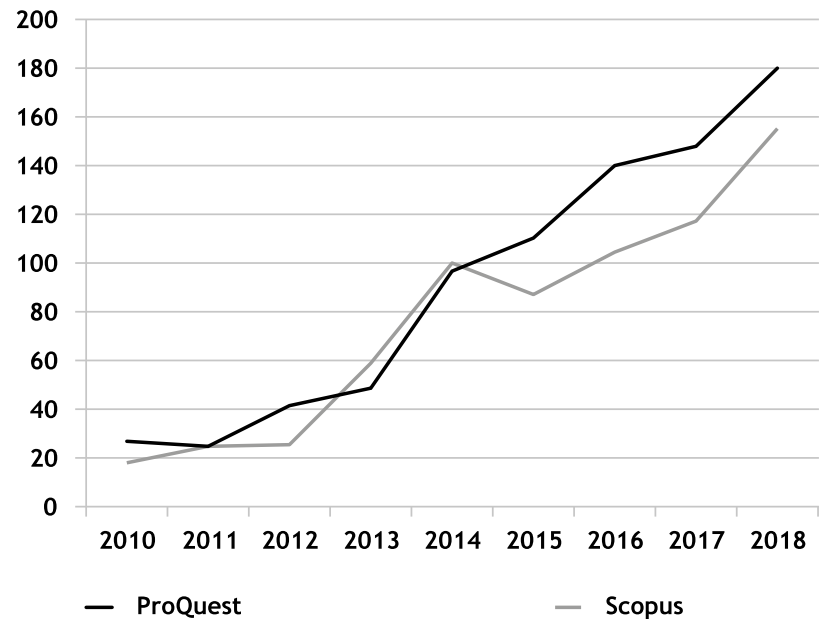

Rys. 1. Występowanie pojęcia „servitization” w bazach danych ProQuest i Scopus

Źródło: opracowanie wtasne na podstawie internetowych baz danych ProQuest i Scopus

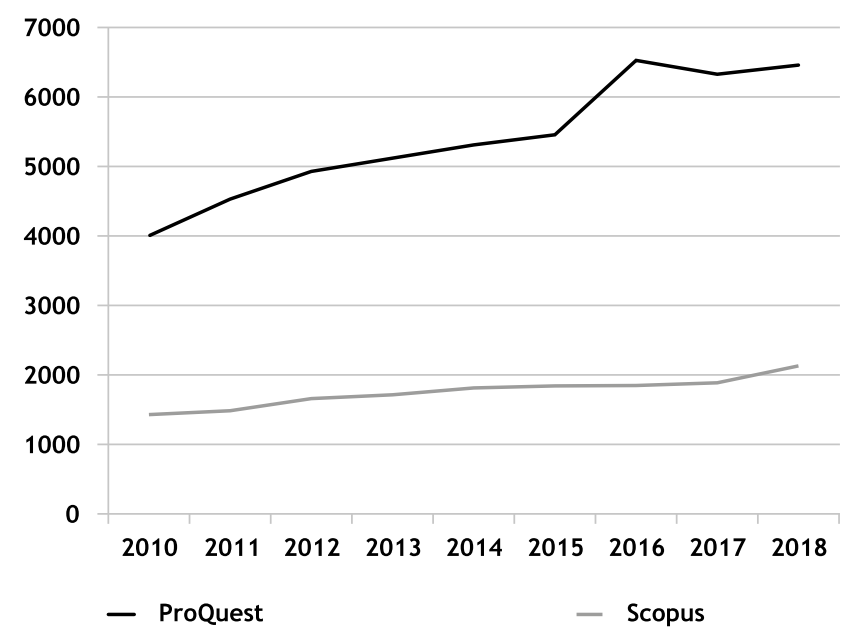

Rys. 2. Występowanie pojęcia „socialization” w bazach danych ProQuest i Scopus

Źródło: opracowanie wtasne na podstawie internetowych baz danych ProQuest i Scopus

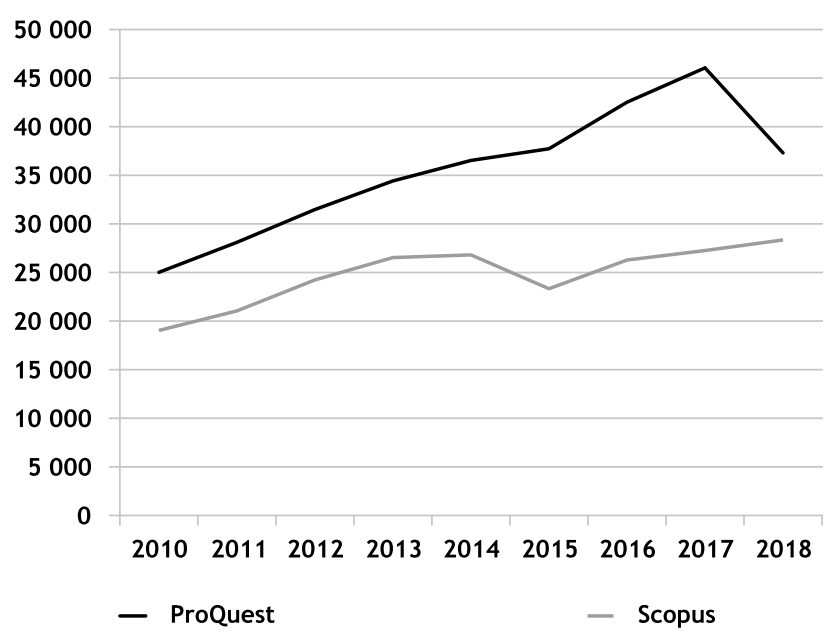

Rys. 3. Występowanie pojęcia „business model” w bazach danych ProQuest i Scopus

Źródto: opracowanie własne na podstawie internetowych baz danych ProQuest i Scopus 
modelu biznesu przedsiębiorstwa. W przedsiębiorstwie, w którym przeoczy się lub zlekceważy pierwsze symptomy kryzysu, mogą one obrócić się szybko w niekorzystną, samonapędzającą się sytuację prowadzącą firmę prosto do krachu. Zmniejszenie obrotów, obniżenie marż oraz spadek sprzedaży, ujemny cashflow i wynikające $\mathrm{z}$ tego postępujące problemy z płatnościami - już wkrótce wzmocnią niepokojące symptomy. Będzie to widoczne nie tylko bezpośrednio w przedsiębiorstwie, lecz także w otoczeniu zewnętrznym - dla udziałowców, dostawców, banków, klientów, doradców i usługodawców, wierzycieli i instytucji publicznoprawnych (Faulhaber, Landwehr, 2001, s. 20).

W kontekście identyfikacji rodzajów strategii restrukturyzacji można wyróżnić ich następujące formuły (Baran, 2004, s. 22-23): ambitną, popularną, marnotrawczą, techniczną, kreatywną, ryzykancką, pokerową, nieracjonalną.

Wyjaśniając istotę restrukturyzacji, należy zwrócić uwagę na ścisłe powiązanie procesu restrukturyzacji z jej celem, czyli oczekiwanymi efektami. Spodziewane efekty podejmowanych przedsięwzięć restrukturyzacyjnych mogą być rozpatrywane $\mathrm{z}$ różnych punktów widzenia - w zależności od charakteru tych efektów, rozległości wpływu, spodziewanego czasu ich wystąpienia, stopnia ich szczegółowości, a wreszcie możliwości ich pomiaru (Borowiecki, 2009, s. 124).

W przypadku przedsiębiorstw działających w gospodarce cyfrowej przedstawione powyżej problemy należy poszerzyć o dodatkowe specyficzne dla cyfrowych modeli biznesu aspekty. Kluczowymi obszarami, które mogą dodatkowo ogniskować na stan biznesu tych firm, są:

1. W zakresie czynników zewnętrznych:

- Kryzys zaufania do usług gospodarki cyfrowej ze względu na obawę użytkowników w zakresie ochrony danych osobowych.

- Niekorzystne zmiany w przepisach prawa w niektórych krajach - różne w różnych miejscach świata, np. kwestie podatkowe, licencjonowanie działalności, inne.

- Bariery rozwoju sektora.

- Niechęć banków do udzielania kredytów firmom świadczącym usługi cyfrowe.

- Nienadążanie systemu prawnego za zmianami technologicznymi.

- Mnogość rozwiązań konkurencyjnych.

2. W zakresie czynników wewnętrznych:

- Dynamiczna migracja wolumenu użytkowników - dynamiczny odpływ dotychczasowych użytkowników i niska dynamika przyrostu nowych.

- Starzejąca się technologia.

- Utrata zdolności do implementacji kreatywnych udoskonaleń.

- Trudności w zakresie zapewnienia transferu środków inwestycyjnych od podmiotów zewnętrznych - migracja środków inwestycyjnych do bardziej atrakcyjnych modeli biznesu.

- Problemy techniczne - usterki, awarie, dysfunkcje, inne.

- Utrata kluczowych specjalistów.

- Starzejący się cyfrowy model biznesu nieadekwatny dla współczesnych potrzeb w zakresie konfiguracji i funkcjonalności.
Przedsiębiorstwa gospodarki cyfrowej podlegają zagrożeniom utraty efektywności ze względu na labilność ich modeli biznesu. Czynnikiem wymagającym uwzględnienia w procesie restrukturyzacji modeli biznesu gospodarki cyfrowej powinno być zmniejszenie poziomu owej labilności. Dlatego też zasadne są badania labilności modeli biznesu w oparciu o następujące założenia (Jabłoński, 2017, s. 13-21):

1. Warunkiem identyfikacji przestrzeni podlegającej labilności modelu biznesu jest ustalenie jego granic.

2. Warunkiem niezbędnym eliminacji labilności modeli biznesu jest umiejętne zarządzanie jego konfiguracją.

3. Warunkiem zarządzania labilnością modeli biznesu jest podejście komponentowe do kształtowania modeli biznesu.

4. Ekonomia współdzielenia (Sharing Economy) w wysokim stopniu powoduje rozchwianie istniejących modeli biznesu w sektorach gospodarki.

5. Nowoczesne technologie zakłócają istniejące ekosystemy, wpływając przy tym na modele biznesu.

6. Nowoczesne modele biznesu oparte na koncepcji Sharing Economy podważają lub zastępują istniejące modele biznesu.

Dlatego też w ujęciu konceptualnym kluczowym zagadnieniem będzie proces zarządzania labilnością cyfrowych modeli biznesu w ich cyklu życia. W kontekście operacjonalizacji zasadna będzie ocena efektywności przyjętego systemu produktowo-usługowego, na bazie którego zaimplementowany jest eksploatowany model biznesu. W końcu istotna będzie ocena atrakcyjności inwestycyjnej modelu biznesu z punktu widzenia zapewnienia dostępu do kapitału.

\section{Ramy teoretyczne i praktyczne cyfrowych modeli biznesu}

Cyfrowe modele biznesu różnią się swoją istotą od modeli biznesu tradycyjnych sektorów gospodarki. Według P. Timmersa (1998, s. 4), cyfrowy model biznesu to konfiguracja architektury produktu, usług i przepływów informacji, w tym opis różnych podmiotów gospodarczych i ich ról oraz opis potencjalnych korzyści dla różnych podmiotów gospodarczych, a także opis źródeł dochodów. Cyfrowe modele biznesu charakteryzują się specyficznym układem cech. O.A El Sawy i F. Pereira (2013) zdefiniowali ramy działania w gospodarce cyfrowej, które składają się z ekosystemu biznesu opartego na interfejsach, roli usługowych platform cyfrowych oraz potrzeby budowy społeczności - ekosystemu wielu aktorów. Cyfrowe modele biznesu w ich ujęciu bazują na identyfikacji pięciu kluczowych komponentów, które nazwali skrótem VISOR: value proposition - propozycja wartości, interface - interakcja między klientem a platformą usług, service platforms - platformy usługowe, organizing model - model organizacyjny, revenue model - model przychodów.

Należy także zwrócić uwagę na klasyfikację w kontekście rynków wielostronnych: wymiar tworzenia wartości (typ platformy, kluczowe działania, sposób prezentacji ceny, system weryfikacji); wymiar dostawy wartości (kluczowa propozycja wartości, treść transakcji, typ transakcji, zakres 
branży, uczestnicy rynku, zasięg geograficzny); wymiar przechwytywania wartości (kluczowy strumień przychodów, mechanizm cenowy, rodzaj dyskryminacji cenowej, źródło przychodów) (Tauscher, Laudien, 2018).

Konstrukcja cyfrowych modeli biznesu jednoznacznie wskazuje na ich uzależnienie od stosowanych technologii, co wynika z potrzeby osadzenia ich w specyficznym ekosystemie technicznym stanowiącym podsystem ekosystemu biznesu, a także od tego, że działają niejako w przestrzeni poza granicami organizacji. Digitalizacja pozwala wyjść poza granice organizacji i osiągać efekty w przestrzeni uzależnionej od dostępności i lokalizacji świadczonych usług.

Digitalizacja jako idea o nastawieniu praktycznym konceptualizowana i operacjonalizowana jest za pośrednictwem modeli biznesu. Kluczową rolę w tym aspekcie odgrywa automatyzacja. Automatyzacja odnosi się do przypadków, w których firma wykorzystuje technologie cyfrowe do automatyzacji lub ulepszenia istniejących działań i procesów. Firmy korzystają z technologii cyfrowych, aby wspierać nowe sposoby prowadzenia biznesu, które uzupełniają, ale nie zastępują całkowicie istniejących działań i procesów (Li, 2017). W praktyce cyfrowe modele biznesu obejmują między innymi takie zagadnienia, jak: IT driving new business, Internet of Things, Cloud technology, Big Data, Mobile technologies, Artificial intelligence and robotic (Sousa, Rocha, 2019, s. 258). Te nowe nurty aktywności gospodarczej sprawiają, że przedsiębiorcze działania są silnie uzależnione od znajomości technologii oraz zdolności do wykrywania nowych potrzeb użytkowników, a także obszarów życia, dla których jest możliwe dokonywanie procesów transformacji cyfrowej.

\section{Serwicyzacja jako nowy kierunek poprawy efektywności przedsiębiorstw}

$\mathbf{Z}$ acieranie się granic pomiędzy produktami i usługami to efekt koncentracji na modelach biznesu stanowiących platformę dla wdrażania produktowo-usługowych systemów biznesowych. Systemy produktowo-usługowe stanowią połączenie produktów i usług, które są usystematyzowane w celu zapewnienia pożądanej użyteczności lub funkcji spełniających potrzeby klientów. Reprezentują podejście do konkretnego rozwiązania, które zapewnia możliwość zaspokojenia indywidualnych potrzeb klientów i zwiększenia konkurencyjności firm (Long i in., 2016). Z definicji systemów produkcyjno-usługowych wyłania się pojęcie serwicyzacji, które stymuluje powstawanie innowacyjnych modeli biznesu. Już w 1988 roku pojęcie to zostało zdefiniowane $\mathrm{w}$ literaturze naukowej przez S. Vandermerwe i J. Rada (1988). Jednak serwicyzacja to zjawisko obserwowane szczególnie w ostatnich latach wynikające $\mathrm{z}$ dynamicznie rosnącej roli usług $\mathrm{w}$ gospodarce światowej, $\mathrm{z}$ nastawieniem na korzystanie $\mathrm{z}$ usług w ramach gospodarstw domowych, a także przedłużaniem łańcuchów dostaw poprzez oferowanie dodatkowej wartości integrującej dostawy produktów z obsługą posprzedażną. Wśród czynników wpływających na rozwój sektora usługowego ważną rolę odgrywa globalizacja, mobilność czynników produkcji, spadek kosztów transakcyjnych i dyfuzja postępu technologicznego. Wszystkie wymienione determinanty stymulują umiędzynarodowienie i fragmentaryzację produkcji oraz wpływają na wzrost zależności zachodzących pomiędzy sektorami gospodarki. Usługi determinują przebieg procesów produkcyjnych, tworzą wartość dodaną i kreują przewagę konkurencyjną danej branży czy przedsiębiorstwa (zjawisko to określane jest jako serwicyzacja) (Ulbrych, 2016, s. 262). Rozkwit cywilizacji usługowej określa się procesem serwicyzacji (Szymańska, 2015, s. 98). Efekt serwicyzacji producenta powoduje, że oprócz kluczowej roli przepływu informacji w dolnej części łańcucha dostaw znaczenia nabierają dostarczane usługi (Matusek, 2017, s. 329). Zatem serwicyzacja określana jest jako przejście od „czystego” produktu do „czystej” usługi (Smith i in., 2014). W ujęciu tradycyjnym to pojęcie determinuje przekształcanie łańcuchów dostaw w łańcuchy usługowe, podczas gdy w przypadku innowacyjnych modeli biznesu serwicyzacja jest już zabudowana w podstawowej idei kształtowania tych modeli biznesu. W tym kontekście pojawiają się nowe obszary kreowania modeli biznesu, rozwijane $\mathrm{z}$ perspektywy świadczonych usług: gospodarka funkcyjna - przedsiębiorstwa nie sprzedają produktów, lecz jego funkcje, gospodarka doznań, a także logika orientacji na usługi (service-dominant logic SD), które stanowią czynniki stymulujące wzrost zainteresowania systemami produkcyjno-usługowymi (Matusek, 2018, s. 346). Serwicyzacja to innowacja zdolności i procesów organizacji do zmiany z koncentracji na sprzedaży produktów do sprzedaży zintegrowanych produktów i usług, które zapewniają wartość użytkową (value in use) (Baines i in., 2009, s. 547). Szczególnie koncepcja S. Vargo dominującej logiki usług (value dominant logic) (Vargo, Lusch, 2006, s. 43-56) stymuluje nowe formuły definiowania wartości (Mahajan, 2017, s. 217-235), która jest czynnikiem decydującym o skuteczności i efektywności projektowanych modeli biznesu, opartych na funkcjonowaniu w ekosystemie usług. Ekosystem jest elementem kontekstu prowadzenia biznesu. J.D. Chandler i S.L. Vargo (2011, s. 35-49) definiują kontekst jako zbiór unikalnych aktorów znajdujących się w unikalnych wzajemnych powiązaniach między nimi. W ten sposób heterogeniczność kontekstu wpływa na sposób wykorzystania zasobów do obsługi. W takim ujęciu projektowane systemy mają charakter konfiguracyjny, łącząc czynniki egzogeniczne i endogeniczne w jeden wspólny system. Systemy konfiguracyjne są coraz częściej wykorzystywane jako środek do efektywnego projektowania niestandardowych systemów obsługi, aby zaspokoić różnorodne potrzeby klientów (Shen i in., 2017, s. 6120). Model biznesu stanowi uosobienie przedmiotowej konfiguracji ze względu na komponentowy układ kształtowania jego postaci. Proces serwicyzacji stanowi kontestację równoległych modeli biznesu firmy - zorientowanych na produkty i usługi (Palo i in., 2018 , s. 1-11). Tak pojmowany proces serwicyzacji może stanowić sposób na przeprowadzenie restrukturyzacji przedsiębiorstw poprzez przekształcenie modelu biznesu zorientowanego na produkty na model biznesu zorientowany na usługi. 


\section{Socjalizacja cyfrowych modeli biznesu}

$\mathrm{C}$ zynnik społeczny ma kluczowe znaczenie dla egzystencji cyfrowych modeli biznesu. Zabudowana idea w konfiguracji modelu biznesu poprzez zastosowanie rozwiązań technologicznych może sprawiać, że jej dostępność jest wręcz nieograniczona. Owa dostępność wspomagana atrakcyjnością może stanowić użyteczną wartość dla bardzo wielu odbiorców - użytkowników. Liczba użytkowników danego cyfrowego modelu biznesu zwiększa szansę na monetyzację modeli biznesu. Dlatego też funkcjonalność proponowanych rozwiązań może generować migrację społeczności ku atrakcyjnym modelom biznesu. Duża społeczność skupiona wokół cyfrowego modelu biznesu to największy kapitał dla jego twórców. Dlatego też nie ulega wątpliwości, że aspekt społeczny stanowi kluczowy nośnik wartości w modelach biznesu (Spieth i in., 2019, s. 427-444). Budowanie dużych społeczności wokół modelu biznesu nie jest proste. Model ten musi wyróżniać się specyficznymi atrybutami, które na tle konkurencyjnych propozycji stworzą szanse przechwycenia wartości z rynku. Dlatego też owo budowanie społeczności jest skuteczniejsze, gdy w modelu biznesu zawarte są aspekty wpływające pozytywnie na etykę biznesu, środowisko naturalne oraz wyniki ekonomiczne. Podział dóbr może nastąpić w sposób zrównoważony tylko wtedy, gdy czynnik ekonomiczny na to pozwala. Od intencji zarządczych menedżerów zależy, w jaki sposób (czy uczciwy i proekologiczny?) zostaną wytworzone dobra i jakie będą one miały wpływ na postrzeganie przez społeczeństwo. W takim kontekście czynniki społeczne mają charakter dwutorowy. $Z$ jednej strony stanowią element budowy kapitału intelektualnego (relacyjnego) - społeczność zwolenników proponowanego rozwiązania. $\mathrm{Z}$ drugiej strony kreowanie wartości powinno odbywać się z poszanowaniem środowiska naturalnego i w sposób uczciwy (przykłady modeli biznesu gospodarki okrężnej).

Przedmiotowa socjalizacja modeli biznesu może stanowić wyróżnik względem konkurencyjnych cyfrowych modeli biznesu walczących o przechwycenie wolumenu społeczności. Wartość zawsze będzie migrować do atrakcyjniejszych pod różnymi względami modeli biznesu.

\section{Wartość strategiczna w cyfrowych modelach biznesu}

K oncepcja wartości jest kluczem do zrozumienia logiki koncepcji modeli biznesu. Wartość jest podstawowym elementem, na bazie której budowane są złożone konstrukty innowacyjnych modeli biznesu. Dominujący charakter ma w modelach biznesu wartość użytkowa (value in use), oczekiwana i doświadczana. Terminy „tworzenie wartości” i „proces tworzenia wartości” są wykorzystywane wyłącznie do tworzenia wartości użytkowej przez klienta. Powodem jest to, że we współczesnej literaturze dotyczącej marketingu i zarządzania, podobnie jak w literaturze dotyczącej aksjologii, klienci są postrzegani jako ci, którzy tworzą wartość z zasobów, które uzyskali (Grönroos, 2011, s. 240-247). Dlatego też wartość w modelach biznesu jest definiowana przez pojęcia kreowanie wartości, przechwytywanie wartości, zatrzymanie wartości, dostawa wartości. Interaktywny, współzależny i dynamiczny charakter współtworzenia wartości doprowadził do poszukiwania przez teoretyków i praktyków lepszego zrozumienia procesów zarządzania wartością w relacjach biznesowych (Corsaro, 2019, s. 99-116). Wartość stanowiąca kombinację cech produktu, usługi i innych zmiennych traktowanych razem stanowi złożoną konstrukcję atrybutów ważnych dla wyboru przez klienta. W ten sposób pojawia się termin wartości strategicznej, czyli tej, która jest równie ważna dla organizacji, jak też klienta, a jest wynikiem unikatowej konfiguracji modelu biznesu. To jej oczekują projektanci innowacyjnych, wygrywających modeli biznesu. W gospodarce cyfrowej wartość strategiczna ma fundamentalne znaczenie $\mathrm{w}$ procesie budowy społeczności, w procesie osiągania oczekiwanej monetyzacji i w procesie budowy reputacji przedsiębiorstw.

\section{Konceptualizacja i operacjonalizacja restrukturyzacji cyfrowych modeli biznesu}

$\mathbf{R}$ estrukturyzacja cyfrowych modeli biznesu ma nieco inny charakter niż restrukturyzacja przedsiębiorstw działających $\mathrm{w}$ tradycyjny sposób. W pierwszej kolejności procesy restrukturyzacyjne powinny odnosić się bezpośrednio do struktury modelu biznesu w kontekście eksploatowanego systemu produktowo-usługowego. Koncentracja na pojedynczych obszarach restrukturyzacji, tak jak to bywa w przypadku restrukturyzacji tradycyjnych firm, nie będzie skuteczna $z$ tego powodu, iż w przypadku przedsiębiorstw gospodarki cyfrowej to model biznesu decyduje w całości o zdolności przedsiębiorstwa do monetyzacji. Jak wskazano wcześniej, cechą cyfrowych modeli biznesu szczególnie we wczesnej fazie rozwoju jest ich labilność, która w wielu przypadkach zaburza procesy monetyzacji. Na potrzeby rozwiązania postawionego problemu naukowego spróbowano w oparciu o przegląd literatury przedmiotu, dyskusję $\mathrm{w}$ środowisku naukowym oraz w oparciu o doświadczenia autora artykułu opracować propozycję modelu restrukturyzacji cyfrowych modeli biznesu w przypadku, gdy poziom labilności tych modeli będzie wysoki, co prowadzi w konsekwencji do zaburzenia procesów monetyzacji finansowej oraz odpływu inwestorów z powodu spadku atrakcyjności inwestycyjnej owego modelu biznesu. Zdefiniowano trzy płaszczyzny, na bazie których powinna być realizowana restrukturyzacja labilnych modeli biznesu gospodarki cyfrowej.

Restrukturyzacja labilnych cyfrowych modeli biznesu może zostać przeprowadzona poprzez łączne zastosowanie trzech kluczowych strategii restrukturyzacji:

1. Strategia serwicyzacji modelu biznesu.

2. Strategia zwiększenia zdolności modelu biznesu do kreacji wartości strategicznej.

3. Strategia socjalizacji modelu biznesu (rys. 4).

Zaproponowany model ma charakter triady uwzględniającej czynniki serwicyzacji modeli biznesu, która polega na maksymalizacji udziału usług w procesie dostawy 
wartości dla klientów - użytkowników. Kolejny obszar stanowi zwiększanie wartości strategicznej, która obejmuje złożony model kreowania, dostawy, przechwytywania i zatrzymania wartości. Jak pisze I.C.L Ng (2014, s. 31), wartość ma charakter kontekstowy i ulotny. Myślenie o wartości w holistycznym ujęciu sprawia, że umiejętne stymulowanie procesami zarządzania wartością w kontekście cyfrowego modelu biznesu decyduje o przetrwaniu i rozwoju tych przedsiębiorstw, stąd ma ona charakter strategiczny. Ideą jest wartość dostarczyć i jej doświadczyć, a doświadczenie to dla użytkownika powinno stanowić wartość strategiczną. Wtedy jest szansa na powszechną akceptację proponowanej propozycji cyfrowego biznesu. Ostatni element przedmiotowej triady dotyczy socjalizacji modelu biznesu. Na bazie czynnika socjalizacji kreowane mogą być skuteczne rozwiązania w sferze społecznych cyfrowych modeli biznesu, które silnie eksponują budowanie postaw prospołecznych w społecznościach ich użytkowników (Jabłoński, Jabłoński, 2020). Kluczowym aspektem efektywności funkcjonowania cyfrowych modeli biznesu jest budowanie społeczności skupionej na realizacji założonej funkcjonalności modelu biznesu. Jeśli następuje odpływ społeczności od modelu biznesu, to należy dokonać analizy, dlaczego tak się dzieje. Często wynika to z powodu braku dostatecznej akceptacji społecznej modelu biznesu - jego społecznej atrakcyjności.

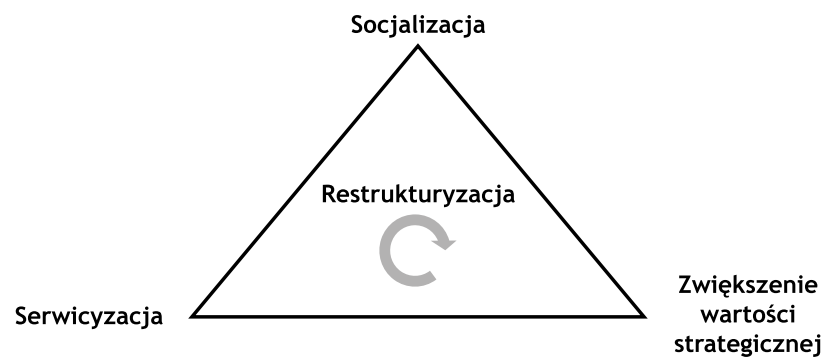

Rys. 4. Koncepcja restrukturyzacji cyfrowych modeli biznesu Źródło: opracowanie wtasne

Rozwiązania oparte na koncepcji Tripple Botom Line (Elkington, 1999), a więc założeniach równowagi czynników ekonomicznych, ekologicznych i etycznych lepiej wpisują się w oczekiwania współczesnych świadomych klientów. Niedostateczny poziom socjalizacji modelu biznesu może zmniejszać poziom jego atrakcyjności i zwiększać przez to poziom labilności. Restrukturyzacja w takim ujęciu służyć ma obniżaniu poziomu labilności cyfrowych modeli biznesu.

\section{Podsumowanie}

W kontekście postawionych pytań badawczych wskazano, że kluczowym problemem funkcjonowania cyfrowych modeli biznesu jest ich labilność. Stąd też cyfrowe modele biznesu muszą znajdować się w permanentnym procesie restrukturyzacji. Restrukturyzacja ta klasyfikuje się do kategorii restrukturyzacji rozwojowej. Opiera się ona na takich działaniach, jak: podejmowanie nowych sfer działania, odnowa asortymentu, zdobycie nowych rynków, intensyfikacja działań w badania i rozwój, wykorzystanie postępu technicznego i technologicznego oraz doskonalenie struktur organizacyjnych i procesów zarządczych (Borowiecki, 2009, s. 123). W przypadku cyfrowych modeli biznesu należy iść nieco dalej, a mianowicie poszukiwać specyficznych i skutecznych metod poprawy efektywności ich działania na konkurencyjnym rynku globalnym. Restrukturyzacja cyfrowych modeli biznesu wpisuje się w paradygmat permanentnej restrukturyzacji (Borowiecki, 2010; Jaki, 2016). Dlatego też w tym kontekście i nurcie badawczym zaproponowano nowy sposób przeprowadzenia procesu restrukturyzacji labilnych cyfrowych modeli biznesu. Równoważenie aspektów serwicyzacji modeli biznesu, ich socjalizacji, a także zwiększania wartości strategicznej powinno doprowadzić do zmniejszenia poziomu labilności tych modeli biznesu i zwiększyć efekt monetyzacji. Ponadto powinno znacząco wpłynąć na ocenę atrakcyjności inwestycyjnej modeli biznesu. W ramach wniosków końcowych należy wskazać następujące konstatacje:

1. Systemy produktowo-usługowe stymulują zmiany w modelach biznesu.

2. Serwicyzacja stanowi kluczowy aspekt procesu permanentnej restrukturyzacji labilnych cyfrowych modeli biznesu.

3. Socjalizacja zwiększać powinna atrakcyjność inwestycyjną modeli biznesu poprzez ich zwiększoną akceptację społeczną oraz uzyskiwany zysk społeczny. Powinna zwiększać wolumen społeczności skupionej na użytkowaniu funkcjonalności danego cyfrowego modelu biznesu.

4. Kreowanie kompleksowej wartości strategicznej opartej na kreowaniu, dostarczaniu, przechwytywaniu i zatrzymaniu wartości stanowi ważny element doskonalenia modeli biznesu dla zmniejszenia ich labilności.

5. Eliminacja labilności modeli biznesu jest celem procesu ich restrukturyzacji.

6. Restrukturyzacja ta ma charakter permanentny.

Zaprezentowane rozważania i wyniki badań wpisują się w obszar zainteresowań naukowych autora artykułu w zakresie poszukiwania przyczyn i zrozumienia czynników odpowiedzialnych za labilność modeli biznesu przedsiębiorstw działających $\mathrm{w}$ gospodarce cyfrowej. Z punktu widzenia obecnych i przyszłych perspektyw badawczych tego tematu ważne jest wskazanie przyczyn i skutków labilności modeli biznesu, szczególnie modeli biznesu spółek wczesnej fazy rozwoju.

dr hab. Marek Jabłoński, prof. uczelni
Wyższa Szkoła Bankowa w Poznaniu
ORCID: 0000-0001-7964-6522
e-mail: marek.jablonski@chorzow.wsb.pl

\section{Bibliografia}

[1] Baines T.S., Lightfoot H.W., Benedettini O., Kay J.M. (2009), The Servitization of Manufacturing, A Review of Literature and Reflection on Future Challenges, „Journal of Manufacturing Technology Management”, Vol. 20, No. 5, pp. 547-567. 
[2] Baran M. (2004), Strategie restrukturyzacyjne w sferze produkcji przemysłowej, Księgarnia Akademicka Uniwersytetu Jagiellońskiego, Kraków.

[3] Blog FUZERS (2018), Serwityzacja. Czy wszystko stanie się usługa? https://fuzers.com/pl/serwityzacja-czy-wszystko-stanie-sie-usluga/, data dostępu: 21.06.2019 r.

[4] Blog thinkle (2019), Systemy produktowo-ustugowe przyszłościa nowoczesnych przedsiębiorstw, https://www.thinkle. $\mathrm{pl} / 2019 / 01 / 16 /$ systemy-produktowo-uslugowe/, data dostępu: $21.06 .2019 \mathrm{r}$.

[5] Borowiecki R. (red.), (2009), Pomiar i ocena procesów kreowania wartości w badaniu efektywności przedsiębiorstwa, Fundacja Uniwersytetu Ekonomicznego w Krakowie, Kraków.

[6] Borowiecki R. (2010), Permanentna restrukturyzacja jako czynnik rozwoju i sukcesu przedsiębiorstw $w$ dobie globalizacji rynku, Zeszyty Naukowe Uniwersytetu Ekonomicznego w Krakowie, Nr 836, s. 27-44.

[7] Chandler J.D., Vargo S.L. (2011), Contextualization and Value-in-context: How Context Frames Exchange, „Marketing Theory", Vol. 11, No. 1, pp. 35-49.

[8] Corsaro D. (2019), Capturing the Broader Picture of Value Co-creation Management, „European Management Journal", Vol. 37, No. 1, pp. 99-116.

[9] El Sawy O.A., Pereira F. (2013), Business Modelling in the Dynamic Digital Space: An Ecosystem Approach, Springer Briefs in Digital Spaces, Springer, Berlin.

[10] Elkington J. (1999), Cannibals with Forks: The Triple Bottom Line of 21st Century Business, Oxford, Capstone.

[11] Faulhaber P., Landwehr N. (2001), Turnaround Management $w$ praktyce - Jak wykorzystać kryzys w przedsiębiorstwie, by odrodziło się na nowo, CeDeWu, Warszawa.

[12] Grönroos C. (2011), A Service Perspective on Business Relationships: The Value Creation, Interaction and Marketing Interface, „Industrial Marketing Management”, Vol. 40, pp. 240-247.

[13] Hakanen T., Helander N., Valkokar K. (2017), Servitization in Global Business-to-business Distribution: The Central Activities of Manufacturers, „Industrial Marketing Management", Vol. 63, pp. 167-178.

[14] Jabłoński M. (2015), Ocena atrakcyjności inwestycyjnej modeli biznesu, Zeszyty Naukowe Uniwersytetu Szczecińskiego, Nr 854, „Finanse, Rynki Finansowe, Ubezpieczenia”, Nr 73, s. 455-468.

[15] Jabłoński M. (2017), Labilność modeli biznesu a zarządzanie interfejsami w koncepcji ekonomii współdzielenia, „Przegląd Organizacji”, Nr 9, s. 13-21.

[16] Jabłoński M. (2019), The Critical Aspects of Value Migration from Volatile Business Models in the Digital Economy, „Journal of Creating Value", Vol. 5, No. 1, pp. 1-14.

[17] Jabłoński A., Jabłoński M. (2020), Social Business Models in the Digital Economy, New Concepts and Contemporary Challenges, Palgrave Macmillan.

[18] Jaki A. (2016), Prowartościowy paradygmat $i$ koncepcja zarzadzania wartościa - mechanizmy i obszary ewolucji, „Przegląd Organizacji”, Nr 1, s. 9-15.

[19] Kohtamäki M., Parida V., Oghazi P., Gebauer H., Baines T. (2019), Digital Servitization Business Models in Ecosystems: A Theory of the Firm, „Journal of Business Research", Vol. 104, pp. 380-392.
[20] Li F. (2017), The Digital Transformation of Business Models in the Creative Industries: A Holistic Framework and Emerging Trends, „Technovation”.

[21] Long H.J., Wang L.Y., Zhao S.X., Jiang Z.B. (2016), An Approach to Rule Extraction for Product Service System Configuration that Considers Customer Perception, „International Journal of Production Research", Vol. 54, No. 18, pp. 5337-5360.

[22] Mahajan G. (2017), Value Dominant Logic, „Journal of Creating Value", Vol. 3, No. 2, pp. 217-235.

[23] Matusek M. (2017), Łańcuch dostaw zintegrowanych rozwiazań produktowo-usługowych - studium przypadku, Zeszyty Naukowe Politechniki Śląskiej, Seria: Organizacja i Zarządzanie, Nr 101, s. 325-338.

[24] Matusek M. (2018), Zjawisko serwicyzacji przedsiębiorstw produkcyjnych - dwoistość ustug $w$ dostarczaniu zintegrowanych rozwiąań produktowo-ustugowych, Zeszyty Naukowe Politechniki Śląskiej, Seria: „Organizacja i Zarządzanie”, Nr 121, s. 343-355.

[25] Ng I.C.L. (2014), Creating New Markets in the Digital Econo$m y$, Value and Worth, Cambridge University Press, New York.

[26] Palo T., Åkesson M., Löfberg N. (2018), Servitization as Business Model Contestation: A Practice Approach, „Journal of Business Research", Vol. 104, pp. 486-496.

[27] Reim W., Sjödin D.R., Parida V. (2019), Servitization of Global Service Network Actors - A Contingency Framework for Matching Challenges and Strategies in Service Transition, "Journal of Business Research", Vol. 104, pp. 461-471.

[28] Shen J., Ahmet Erkoyuncu J., Roy R., Wu B. (2017), A Framework for Cost Evaluation in Product Service System Configuration, „International Journal of Production Research”, Vol. 55, No. 20, pp. 6120-6144.

[29] Smith L., Maull R., Ng I.C.L. (2014), Servitization and Operations Management: A Service Dominant Logic Approach, „International Journal of Operations \& Production Management", Vol. 34, No. 2, pp. 242-269.

[30] Sousa M.J., Rocha Á. (2019), Skills for Disruptive Digital Business, „Journal of Business Research”, Vol. 94, pp. 257-263.

[31] Spieth P., Schneider S., Clauß T., Eichenberg D. (2019), Value Drivers of Social Businesses: A Business Model Perspecti$v e$, ,Long Range Planning”, Vol. 52, No. 3, pp. 427-444.

[32] Szymańska E. (2015), Serwicyzacja gospodarki jako źródło jej transformacji, „Optimum. Studia Ekonomiczne”, Nr 1(73), s. 97-109.

[33] Timmers P. (1998), Business Models for Electronic Markets, „Electronic Markets”, Vol. 8, No. 2, pp. 3-8.

[34] Tukker A. (2004), Eight Types of Product - Service System: Eight Ways to Sustainability? Experiences from Suspronet, „Business Strategy and the Environment”, Vol. 13, No. 4, pp. 246-260

[35] Tauscher K., Laudien S.M. (2018), Understanding Platform Business Models: A Mixed Methods Study of Marketplaces, „European Management Journal”, Vol. 36, No. 3, pp. 319-329.

[36] Ulbrych M. (2016), Serwicyzacja produkcji przemysłowej. Wnioski dla Polski, „Finanse, Rynki Finansowe, Ubezpieczenia”, Nr 3(81), s. 253-264.

[37] Vandermerwe S., Rada J. (1988), Servitization of Business: Adding Value by Adding Services, „European Management Journal”, Vol. 6, No. 4, pp. 314-324. 
[38] Vargo S.L., Lusch R. (2006), Service-dominant Logic: What It Is, What It Is not, What It Might Be, [in:] R. Lusch, S.L. Vargo (eds.), The Service - Dominant Logic of Marketing, Dialog, Debate, and Directions, M.E. Sharpe, Armonk, pp. 43-56.

\section{Restructuring Digital Business Models - Attempt at Conceptualization}

\section{Summary}

The article presents the problem domain related to key aspects of the restructuring of volatile digital business models restructuring through their servitization, socialization and strategic value which is created by features of business models. Servitization based on the assumptions of product and service systems is a stimulator of business models effectiveness. Digital business models due to the dynamic technological progress and changing customer needs are becoming labile. Their instability causes that they must be in a permanent restructuring process. The proposed model for restructuring digital business models is based on a triad of three key components, namely: servitization, socialization and the strategic value of business models. Ensuring a balance between these elements can lead to the success of enterprises operating in the digital economy. The aim of the article is to indicate a new approach to developing the model for restructuring digital business models.

\section{Keywords}

restructuring, digital business models, servitization, volatile business models 